\title{
Analysis of Five Arboviruses and Culicoides Distribution on Cattle Farms in Jeollabuk-do, Korea
}

\author{
Daram Yang', Myeon-Sik Yang1', Haerin Rhim¹, Jae-Ik Han¹, Jae-Ku Oem¹, Yeon-Hee Kim², Kyoung-Ki Lee², \\ Chae-Woong Lim¹, Bumseok Kim,* \\ ${ }^{1}$ College of Veterinary Medicine and Korea Zoonosis Research Institute, Chonbuk National University, Iksan 54596, Korea; \\ ${ }^{2}$ Animal Disease Diagnostic Division, Animal and Plant Quarantine Agency, Gimcheon 39660, Korea
}

\begin{abstract}
Arthropod-borne viruses (Arboviruses) are transmitted by arthropods such as Culicoides biting midges and cause abortion, stillbirth, and congenital malformation in ruminants, apparently leading to economic losses to farmers. To monitor the distribution of Culicoides and to determine their relationship with different environmental conditions (temperature, humidity, wind speed, and altitude of the farms) on 5 cattle farms, Culicoides were collected during summer season (May-September) in 2016 and 2017, and analyzed for identification of species and detection of arboviruses. About 35\% of the Culicoides were collected in July and the collection rate increased with increase in temperature and humidity. The higher altitude where the farms were located, the more Culicoides were collected on inside than outside. In antigen test of Culicoides against 5 arboviruses, only Chuzan virus (CHUV) (2.63\%) was detected in 2016. The Akabane virus (AKAV), CHUV, Ibaraki virus and Bovine ephemeral fever virus (BEFV) had a positive rate of less than 1.8\% in 2017. In antigen test of bovine whole blood, AKAV (12.96\%) and BEFV (0.96\%) were positive in only one of the farms. As a result of serum neutralization test, antibodies against AKAV were generally measured in all the farms. These results suggest that vaccination before the season in which the Culicoides are active is probably best to prevent arbovirus infections.
\end{abstract}

Key words: Culicoides biting midges, arbovirus, akabane virus, cattle, Korea

\section{INTRODUCTION}

Culicoides biting midges (Diptera: Ceratopogonidae) are the smallest haematophagous insects, which transmit the fatal virus to ruminants [1]. More than 1,400 species of Culicoides have been described and present on all land with the exception of Antarctica and New Zealand [1,2]. A size of Culicoides is around 1-3 $\mathrm{mm}$, and they have a complete metamorphosis life cycle going through the egg, larva, pupa, and adult stages $[1,3]$. Females preparing to spawn after mating with males suck up blood of human or animal to get animal protein at dawn or dusk [1,3]. Breeding sites of Culicoides are watery and nutritious streams that can help them grow and develop larvae [4]. Adult Culicoides have different wing patterns based on species, which helps in easy identification of different species [5].

Arthropod-borne viruses (arboviruses) are major pathogens

- Received 13 March 2018, revised 16 August 2018, accepted 2 September 2018.

*Corresponding author (bskims@jbnu.ac.kr)

(c) 2018, Korean Society for Parasitology and Tropical Medicine

This is an Open Access article distributed under the terms of the Creative Commons Attribution Non-Commercial License (http://creativecommons.org/licenses/by-nc/4.0) which permits unrestricted non-commercial use, distribution, and reproduction in any

medium, provided the original work is properly cited. in the veterinary field and are transmitted by arthropods such as Culicoides biting midges [1]. Arboviruses infected with ruminants cause abortion, stillbirth, and congenital malformation $[6,7]$. Akabane virus (AKAV) and Aino virus (AINOV) belong to the family Peribunyaviridae $[1,8]$. Sporadic outbreaks of AKAV have been reported widely in Japan, Southeast Asia and the Middle East, including Korea [9-12]. In Japan, JaGAr39, the prototype of AKAV, was first isolated in 1959 [9]. In Korea, a case of AKAV was first reported in 1980 [12]. In 2010, meningitis associated with AKAV infection occurred in a large-scale in South Korea [13]. More than 500 cattle exhibited symptoms such as movement disorder, trembling, and in severe cases, the cattle exhibited an inability to stand. Chuzan virus (CHUV) and Ibaraki virus (IBAV) are members of the family Reoviridae $[1,14]$. CHUV was first emerged in Japan, 1985, and the clinical signs are neurological abnormalities and hydranencephaly [15]. IBAV infection is characterized by fever, salivation, anorexia, and a deglutitive disorder in cattle. Symptoms except deglutitive disorder with dysphagia are usually mild. Bovine ephemeral fever virus (BEFV) grouped in the family Rhabdoviridae is similar to the IBAV, which is characterized by acute fever [14]. High fever, nasal discharges, salivation, and inability to stand 
appear to the principal signs of cattle infected with BEFV.

The surface temperature of the earth is rising continuously due to global warming, which is expected to rise further [3]. Temperature is one of the environmental factors that affect the activity of poikilothermic Culicoides [16,17]. Viruses that spread faster due to increased vector activity in warmer atmospheric temperatures result in severe economic losses in the industrial animal field. The aim of this study was to investigate the Culicoides distribution in different cattle farms in the area where encephalomyelitis occurred on a large-scale in 2010, and environmental conditions which affect the Culicoides abundance.

\section{MATERIALS AND METHODS}

\section{Collection and identification of Culicoides biting midges}

Culicoides biting midges were collected once (2016) or twice (2017) per month using a light trap (SNC, Hanam, Korea) from 5 different cattle farms located in Gimje (35 $50^{\prime} 34.4389^{\prime \prime}$ N; 126 ${ }^{\circ} 51^{\prime 2} 21.3368^{\prime \prime}$ E), Gochang ( $35^{\circ} 24^{\prime} 42.0937^{\prime \prime} \mathrm{N} ; 126^{\circ} 39^{\prime} 05$. 0940" E), Wanju (36 03'20.7356" N; 127 11'12.1909" E), Jinan $\left(35^{\circ} 51^{\prime} 17.6353^{\prime \prime} \mathrm{N} ; 127^{\circ} 20^{\prime} 19.2646^{\prime \prime} \mathrm{E}\right)$ and Namwon (35 $29^{\prime} 32$. $7782^{\prime \prime} \mathrm{N} ; 127^{\circ} 38^{\prime} 42.2509^{\prime \prime} \mathrm{E}$ ) areas, Jeollabuk Province from May to September in 2016 and 2017 (Supplementary Fig. S1). Each region differed in altitudes (about $50 \mathrm{~m}, 50 \mathrm{~m}, 300 \mathrm{~m}$, $500 \mathrm{~m}$ and $600 \mathrm{~m}$ respectively).

Used light trap consisted of $8 \mathrm{~W} \mathrm{UV} \mathrm{fluorescent} \mathrm{light} \mathrm{with} \mathrm{a}$ downdraft suction fan. The traps were located inside and outside (about $200 \mathrm{~m}$ from breeding farms) the farms to compare the differences in collection rates. The traps were set in the afternoon before sunset and were collected the next morning within $1 \mathrm{hr}$ after sunrise. Collected Culicoides samples were sorted morphologically into species according to their wing patterns observed under the microscope $[18,19]$. After classification, Culicoides (-30) were pooled into one sample based on collection date and species.

During June and July, whole blood of cattle (over six months) was drawn from the jugular vein using $10 \mathrm{ml}$ syringes. Collected samples were into vacuum tubes treated anticoagulant, ethylenediaminetetraacetic acid (EDTA), and mixed.

\section{Measurement of temperature, humidity, and wind speed}

The temperature and humidity were measured using a digital thermo-hygrometer machine (LAVISEN, Namyangju, Korea) and the wind speed data were obtained through the Korea Meteorological Administration (http://www.kma.go.kr).

\section{DNA/RNA extraction and Reverse transcription PCR analysis}

Pooled Culicoides samples were homogenized using a Handheld Pestle Cordless Motor (BIOFACT, Daejeon, Korea) with $500 \mu \mathrm{l}$ of Dulbecco's Modified Eagle's Medium (DMEM). Homogenized samples were centrifuged at 13,000 rpm for 10 min at $4^{\circ} \mathrm{C}$ and the supernatant was used for DNA/RNA extraction using a Patho Gene-spin ${ }^{\mathrm{TM}}$ DNA/RNA Extraction Kit (iNtRON, Seongnam, Korea) according to the manufacturer's instructions. Bovine whole blood was centrifuged at 13,000 rpm for $5 \mathrm{~min}$ to get buffy coat and plasma. Collected supernatant was used for virus DNA/RNA extraction using a MinElute Virus Spin Kit (QIAamp, Hilden, Germany).

Extracted Culicoides and blood DNA/RNA samples were tested to detect 5 arboviruses (AKAV, AINOV, CHUV, IBAV and BEFV) using VDx ${ }^{\circledR}$ Single RT-PCR Kit (MEDIAN Diagnostics, Chuncheon, Korea). Table 1 showed the information including primer sequences used, target gene, and size. PCR program is as follows: CDNA synthesis at $50^{\circ} \mathrm{C}$ for $30 \mathrm{~min}$ and initial inactivation at $95^{\circ} \mathrm{C}$ for $15 \mathrm{~min}$ in the first cycle followed by 40 cycles of denaturation at $94^{\circ} \mathrm{C}$ for $20 \mathrm{sec}$, annealing at $55^{\circ} \mathrm{C}$ for $30 \mathrm{sec}$ and extension at $72^{\circ} \mathrm{C}$ for $40 \mathrm{sec}$. Lastly, a final exten-

Table 1. Sequences of primer used and target information

\begin{tabular}{|c|c|c|c|c|}
\hline No. & Target Virus & Primer & Gene & Size (bp) \\
\hline 1 & AKAV & $\begin{array}{l}\text { J424F: 5'-CAGAAGAAGGCCAAGATGGT-3' } \\
\text { J425R: 5'-AATGCAGCCTTGACTGCGTCC-3' }\end{array}$ & $\begin{array}{l}\text { S segments } \\
\mathrm{N} \text { gene }\end{array}$ & 476 \\
\hline 3 & CHUV & $\begin{array}{l}\text { J427F: 5'-CTGGCTाTCTGAGGCGTाC-3' } \\
\text { J428R: 5'-GGTTGCTCAATATGCCAAGCGA-3' }\end{array}$ & NS1 (S5) & 306 \\
\hline 4 & IBAV & $\begin{array}{l}\text { J431F: 5'-AGGATACGGAGGCGGCCTTCT-3' } \\
\text { J432R: 5'-CCGGAGATACCTCCATTACC-3' }\end{array}$ & S segment3 & 411 \\
\hline 5 & BEFV & $\begin{array}{l}\text { J429F: 5'-CGGTTGCACAGATGCGGTTAAG-3' } \\
\text { J430R: 5'-GACTCTCACATCTGGTATCC-3' }\end{array}$ & G & 262 \\
\hline
\end{tabular}


sion was carried out at $72^{\circ} \mathrm{C}$ for $5 \mathrm{~min}$ in the last cycle [20].

\section{Gel electrophoresis}

Amplification samples ( $5 \mu \mathrm{l}$ ) were analyzed by electrophoresis in $1.5 \%$ agarose gels (GeneDireX ${ }^{\circledR}$, Taiwan) containing $0.5 \mathrm{ml}$ of RedSafe ${ }^{\mathrm{TM}}$ (iNtRON). Typically, $6 \mu \mathrm{l}$ of 100 bp marker and samples were loaded in the gel and run at $100 \mathrm{~V}$ for 25 min. Subsequently, the gel images were captured using ImageQuant ${ }^{\mathrm{TM}}$ LAS 500 (GE Healthcare Life Science, Pittsburgh, Pennsylvania, USA).

\section{Serology analysis in bovine blood against arboviruses}

The AKAV strain 93FMX (KVCC-VR63), AINOV strain KSA 9910 (Korea Veterinary Culture Collection (KVCC) VR64), CHUV strain YongAm (KVCC-VR66), IBAV strain 08220 (KVCCVR65) and BEFV strain TongRae (KVCC VR41) were used for serum neutralization tests (SNT) $[8,20]$. Vero cells (ATCC,
C-1586) were maintained in alpha- minimum essential medium (Gibco, Grand Island, New York, USA) supplemented with $5 \%$ fetal bovine serum and antimycoticantibiotics (Gibco). Bovine serum diluted to 2-fold serial was mixed with equal volumes of virus containing $200 \mathrm{TCID}_{50} / 0.1 \mathrm{ml}$ and inoculated with Vero cells $[8,20,21]$. The plates were microscopically examined after 3 and 5 days to find virus-specific cytopathic effects (CPE). Antibody titer was defined as the reciprocal of the highest serum dilution at which CPE was inhibited. A titer of 4 folds or greater was considered to be positive.

\section{RESULTS}

\section{Collected numbers of Culicoides species}

In 2016, a total of 4,932 Culicoides were collected (Table 2; Fig. 1A). Collected Culicoides species were C. arakawae $(\mathrm{n}=2,988$, $60.6 \%)$, C. punctatus $(\mathrm{n}=1,497,30.4 \%)$, C. nipponensis $(\mathrm{n}=246$,

Table 2. Information about collected Culicoides species in 2016 and 2017

\begin{tabular}{|c|c|c|c|c|c|c|c|}
\hline \multirow{2}{*}{ Year } & \multirow{2}{*}{ Region } & \multirow{2}{*}{ Total number } & \multicolumn{5}{|c|}{ Species } \\
\hline & & & C. arakawae & C. punctatus & C. tainanus & C. nipponensis & Culicoides spp. \\
\hline \multirow[t]{5}{*}{2016} & Wanju & 605 & $272(45.0)$ & 264 (43.5) & $36(6.0)$ & 0 & $33(5.5)$ \\
\hline & Gochang & 1,237 & 868 (70.2) & $93(7.4)$ & $2(0.2)$ & $246(19.9)$ & $28(2.3)$ \\
\hline & Gimje & 304 & $295(97.0)$ & $6(2.0)$ & $2(0.7)$ & 0 & $1(0.3)$ \\
\hline & Jinan & 1,328 & $996(75.0)$ & $294(22.1)$ & $9(0.7)$ & 0 & $29(2.2)$ \\
\hline & Total & 4,932 & 2,988 (60.6) & $1,497(30.4)$ & $61(1.2)$ & $246(5.0)$ & $140(2.8)$ \\
\hline \multirow[t]{5}{*}{2017} & Wanju & 664 & 348 (52.4) & 309 (46.5) & $4(0.6)$ & 0 & $3(0.5)$ \\
\hline & Gochang & 2,904 & 2,636 (90.8) & $165(5.7)$ & $2(0.1)$ & $87(3.0)$ & $14(0.5)$ \\
\hline & Gimje & 220 & $215(97.7)$ & $5(2.3)$ & 0 & 0 & 0 \\
\hline & Jinan & 2,981 & $2,129(71.4)$ & $813(27.3)$ & $23(0.8)$ & 0 & $16(0.5)$ \\
\hline & Namwon & 3,954 & $2,011(50.9)$ & 1,927 (48.7) & $6(0.2)$ & 0 & $10(0.3)$ \\
\hline
\end{tabular}

A

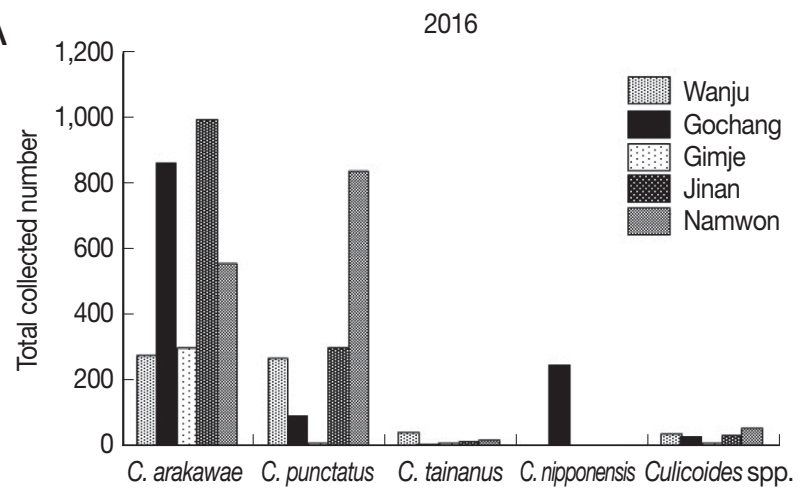

B

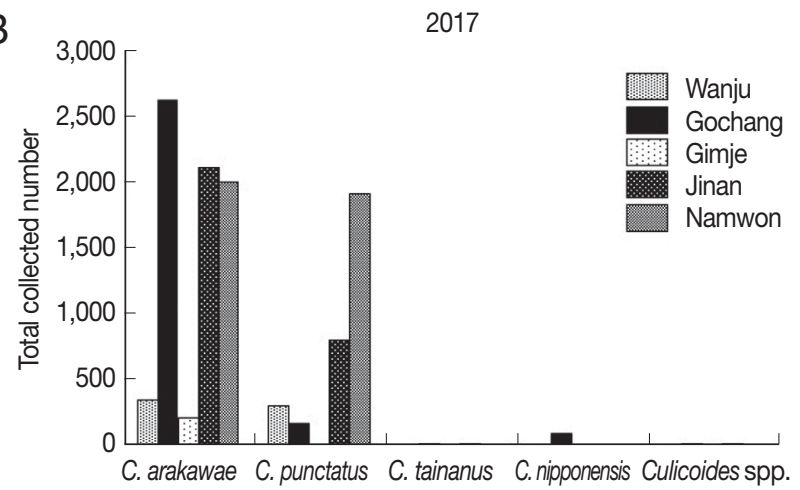

Fig. 1. Collected Culicoides species and numbers in 2016 (A) and 2017 (B). According to results of Culicoides collection in 2016 (once per month) (A) and 2017 (twice per month) (B), dominant species was C. arakawae, followed by C. punctatus. C. nipponensis was only collected in Gochang. 
5.0\%), C. tainanus ( $\mathrm{n}=61,1.2 \%)$ and Culicoides spp. $(\mathrm{n}=140$, $2.8 \%$ ). Dominant species were $C$. arakawae in 4 farms whereas C. punctatus was dominant in one farm (Namwon). C. nipponensis was collected only in one farm (Gochang).

A total of 10,723 Culicoides were collected in 2017 (Table 2; Fig. 1B). Species such as $C$. arakawae $(\mathrm{n}=7,339,68.4 \%), C$. punctatus ( $\mathrm{n}=3,219,30.0 \%), C$. nipponensis $(\mathrm{n}=87,0.8 \%), C$. tainanus ( $\mathrm{n}=35,0.3 \%)$ and Culicoides spp. $(\mathrm{n}=43,0.4 \%)$ were collected. C. arakawae was dominant species in all the regions and C. nipponensis was collected only in one farm (Gochang) similar to the collection in 2016.

\section{Comparison of collected Culicoides numbers between inside and outside the cattle farms}

Different collection rates of Culicoides inside and outside the cattle farms were observed depending on different altitudes.

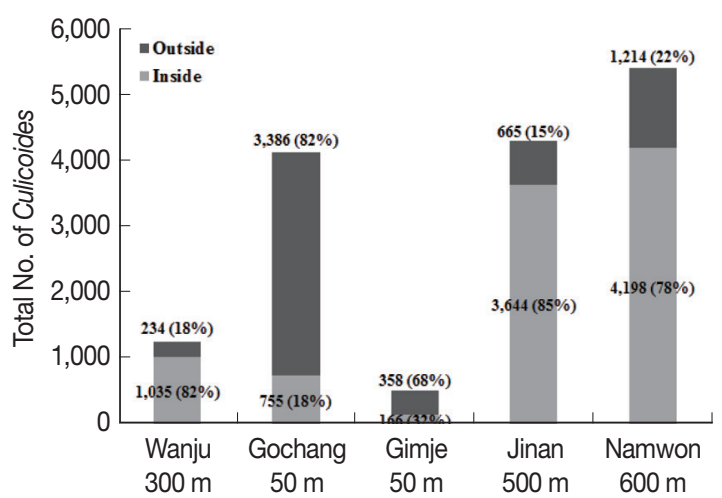

Fig. 2. Comparison of numbers of Culicoides collected between inside and outside the cattle farms. A majority of Culicoides were collected from low altitude area outside the farms compared to inside the farm. At farms located at relatively high altitude, more Culicoides were collected from inside the farm as compared to outside the farm.
The outside of the cattle farms located at low altitude (about $50 \mathrm{~m}$ ) showed higher collection rates than inside the farm (Fig. 2). On the other hand, collection rates of Culicoides were higher inside the farm located at high altitude (over $300 \mathrm{~m}$ ) compared to the outside of cattle farms.

\section{Distribution of collected Culicoides species month-wise}

Overall, the number of collected Culicoides was mainly concentrated in July 2016 (Fig. 3A) and 2017 (Fig. 3B). A total of 1,871 Culicoides were collected in July followed by June $(\mathrm{n}=1,084)$, August $(\mathrm{n}=967)$, September $(\mathrm{n}=740)$, and May $(\mathrm{n}=307)$ in 2016. In 2017, a total of 3,618 Culicoides were collected in July and followed by August $(\mathrm{n}=3,075)$, June $(\mathrm{n}=2,063)$, May $(\mathrm{n}=1,002)$, and September $(\mathrm{n}=965)$. Generally, $C$. arakawae was the most collected species during each month.

\section{Correlation between collection rates of Culicoides and temperature, humidity, and wind speed}

Three environmental factors (temperature, humidity, and wind speed) were recorded on the collection dates of Culicoides. The mean temperature was in the range of $16.4-26.9^{\circ} \mathrm{C}$, and the mean humidity was in the range of $67.4-88.1 \%$. The mean wind speed ranged from 1 to $2 \mathrm{~m} / \mathrm{sec}$. On the conditions of $25.3^{\circ} \mathrm{C}$ temperature, $87.3 \%$ humidity, and $1.6 \mathrm{~m} / \mathrm{sec}$ of mean wind speed, the highest mean number of Culicoides collected was 364 . On the other hand, the lowest mean number of Culicoides collected was 91 at $20.2^{\circ} \mathrm{C}$ temperature, $80 \%$ humidity, and $1.8 \mathrm{~m} /$ sec of mean wind speed. Culicoides tended to be more collected at a high mean temperature and humidity (Fig. 4A, B). There was no effect of mean wind speed on the rates of Culicoides collection (Fig. 4C).
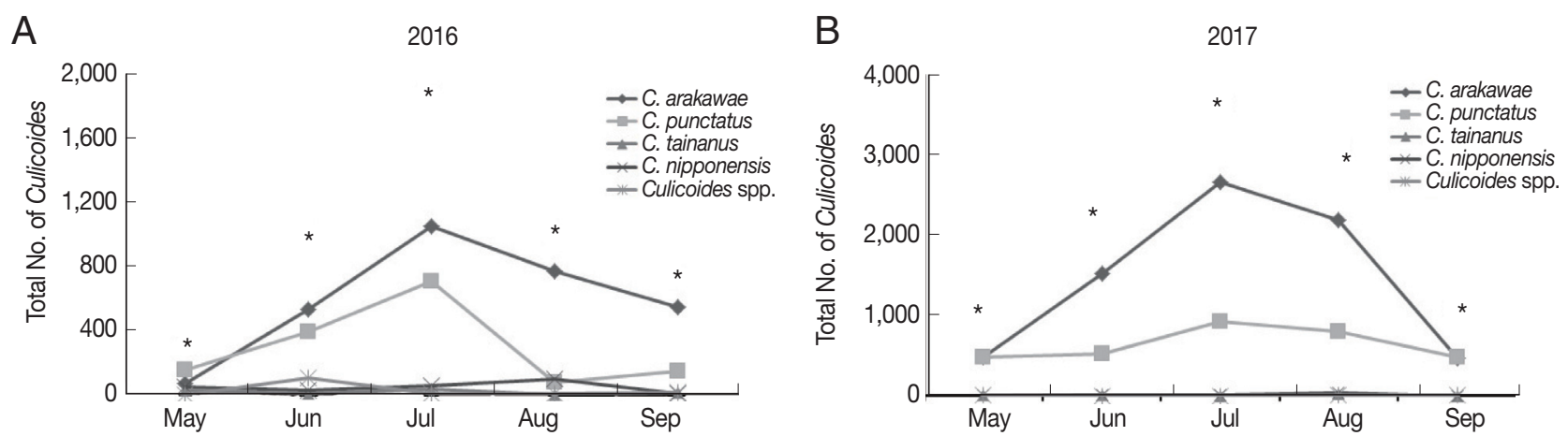

Fig. 3. Distribution of collected Culicoides species in the months of 2016 (A) and 2017 (B). *Total number of collected culicoicles species. 
Antigen detection of Culicoides and bovine whole blood against 5 arboviruses

Collected Culicoides were conducted to test the positive rates against 5 arboviruses. In 2016, only CHUV was detected twice in Jinan cattle farm with a positive rate of $2.63 \%$ in 2 of the 76 poolings (Table 3A). Each species of poolings showing positive were C. arakawae and C. punctatus. In 2017, 3 of the 166 poolings were positive for AKAV, 2 for CHUV, one for IBAV, and one for BEFV. AKAV were detected in one $C$. arakawae pooling at Gochang and 2 C. arakawae poolings at the farm located in Jinan with a positive rate of $1.81 \%$. Two CHUV were detected in one $C$. arakawae pooling and one C. punctatus pooling at the farm located in Namwon with a positive rate of 1.20\%. IBAV and BEFV were positive in each C. punctatus and C. arakawae at the farm located in Wanju with a positive rate of $0.60 \%$. In antigen test of bovine blood against 5 arboviruses, the antigen to AKAV (12.96\%) and antigen to BEFV $(0.93 \%)$ were detected in samples collected from the farm located in Gochang (Table 3B). To confirm the identification of arbovirus-specific detection, Basic Local Alignment Search
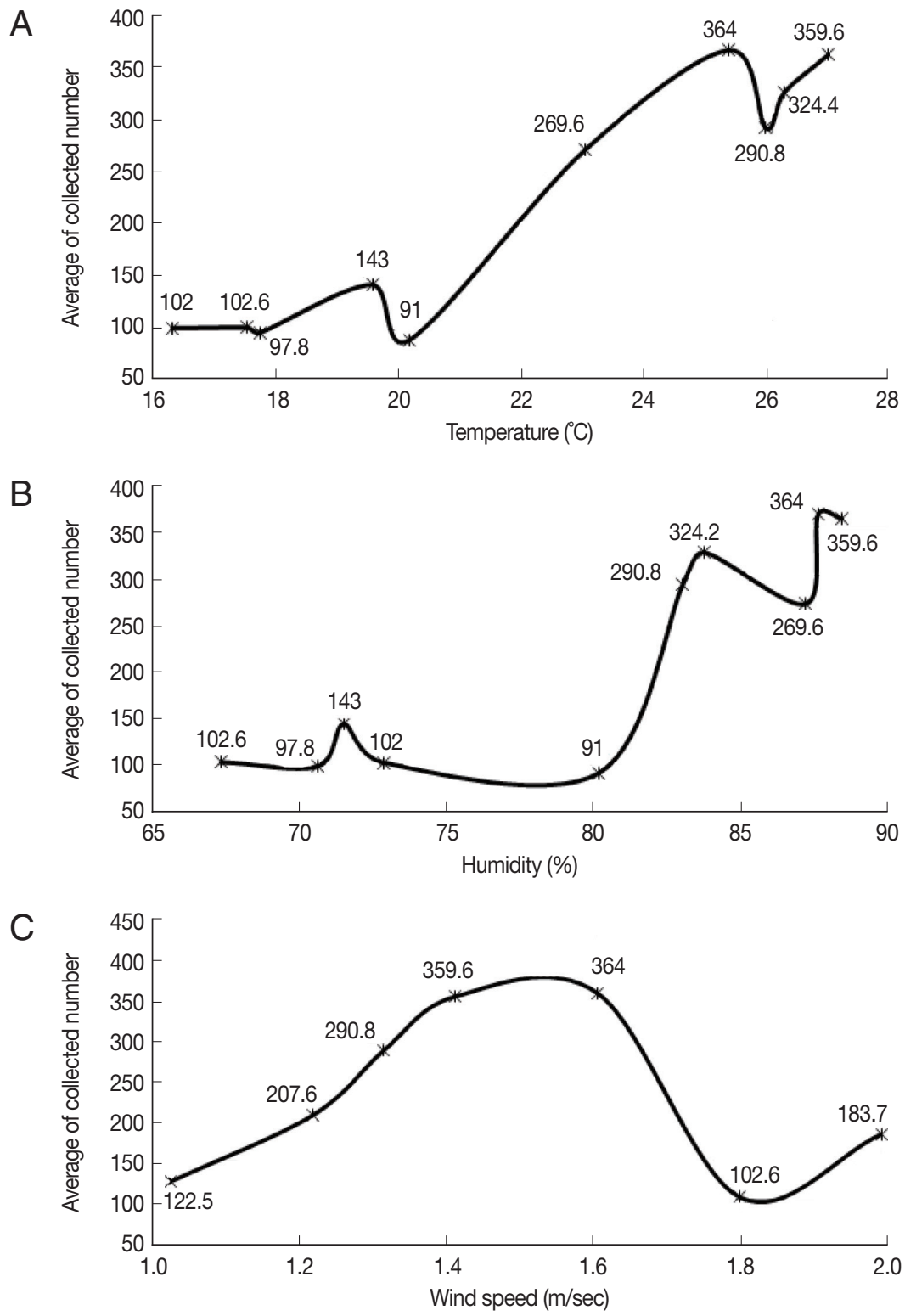

Fig. 4. Correlation between the number of collected Culicoides and temperature (A), humidity (B), and wind speed (C). More Culicoides were collected at higher temperature and humidity. Collected Culicoides was concentrated at 1.4-1.6 m/s. 
Table 3. Antigen detection of Culicoides and bovine whole blood against 5 arboviruses

(A) In results of antigen detection rates against arboviruses in Culicoides, AINOV was not detected in any year, and CHUV was detected in 2016 (2.63\%) and 2017 (1.20\%). All of the detected viruses showed a detection rate within 3\%

\begin{tabular}{|c|c|c|c|c|c|}
\hline \multirow{2}{*}{ Year } & \multicolumn{5}{|c|}{ Arboviruses } \\
\hline & AKAV & AINOV & CHUV & IBAV & BEFV \\
\hline \multirow[t]{2}{*}{2016} & - & - & $2.63 \%(2 / 76)$ & - & - \\
\hline & & & $\begin{array}{r}\text { In Jinan, } 1 \text { C. arakawae } \\
1 \text { C. punctatus }\end{array}$ & & \\
\hline \multirow[t]{2}{*}{2017} & $1.81 \%(3 / 166)$ & - & $1.20 \%(2 / 166)$ & $0.60 \%(1 / 166)$ & $0.60 \%(1 / 166)$ \\
\hline & $\begin{array}{l}\text { In Gochang, } 1 \text { C. arakawae } \\
\text { In Jinan, } 2 \text { C. arakawae }\end{array}$ & & $\begin{array}{r}\text { In Namwon, } 1 \text { C. arakawae } \\
1 \text { C. punctatus }\end{array}$ & In Wanju, 1 C. punctatus & In Wanju, 1 C. arakawae \\
\hline
\end{tabular}

(B) In bovine blood, only AKAV and BEFV were detected. The test was not carried out in Jinan

\begin{tabular}{lcccc}
\hline \multirow{2}{*}{ Region } & \multicolumn{3}{c}{ Arboviruses } \\
\cline { 2 - 5 } & AKAV $(\%)$ & AINOV $(\%)$ & CHUV $(\%)$ & BEFV (\%) \\
\hline Wanju $(n=20)$ & 0 & 0 & 0 & 0 \\
Gochang $(n=108)$ & $12.96(14 / 108)$ & 0 & 0 & 0 \\
Gimje $(n=20)$ & 0 & 0 & 0 & 0 \\
Namwon $(n=42)$ & 0 & 0 & 0 & 0 \\
Jinan & & & The test was not carried out.
\end{tabular}

Tool (BLAST) was conducted with bi-directional sequencing data of positive samples. The results showed that over $92 \%$ identity was observed in individual arboviruses (Supplementary Table S1).

\section{Serum neutralization tests against 5 arboviruses}

As a result of antibody test against arboviruses in bovine serum, antibody to $\operatorname{AKAV~(3.57\% ,~25.00\% ,~5.56\% ,~33.33\% ,~and~}$ $11.36 \%$ ) was positive in all the 5 farms (Table $4 \mathrm{~A}$ ). Antibody to CHUV (3.57\% and 5.00\%) was detected in blood samples collected from 2 farms (Wanju and Gochang). The antibody titer of BEFV detected was particularly high (64.29\%) in blood samples collected from the farm located in Wanju (Table 4B). There were cases that 2 or more arboviruses were detected in one cattle in Wanju (21.4\%) and Gochang (17.5\%).

\section{DISCUSSION}

Transmission of arthropod-borne viral disease is difficult to prevent as they cannot be visually observed and spread quickly and widely. Surveillance has steadily been conducted in several countries to investigate the distribution of Culicoides that is a vector of arboviruses, and to test against target viruses for predicting the outbreak $[2,22,23]$. As these investigations have been carried out for a long time, haematophagous vector collection methods have been developed on a variety of occa- sions, such as collection means using UV light with a wide range of wavelengths [24], and traps in which carbon dioxide $\left(\mathrm{CO}_{2}\right)$ is released at diverse concentrations to attract Culicoides [25]. They showed that the standard CDC UV light trap collected the Culicoides significantly more than the normal LED trap, and $\mathrm{CO}_{2}$ trap releasing decanal or phenol collected highly compared to trap with $\mathrm{CO}_{2}$ alone. These results will be a useful source to collect Culicoides more effectively. In addition, new species of Culicoides as a vector of arboviruses are continuously being discovered [25-27]. In Korea, new Culicoides species were discovered in 2013 [28]. Therefore, epidemiological studies on arthropod-borne are expected to experience continual growth.

In 2016 and 2017, a total number of 15,655 Culicoides were collected during the collection period. The species were classified as C. arakawae, C. punctatus, C. nipponensis and C. tainanus. In this study, C. arakawae was the extensively collected species while C. arakawae which is a transvector of leucocytozoon disease in Japan was generally collected from the chicken farm [29]. Previous studies showed that C. arakawae was rarely found in ruminant farms and is blood-sucking midges which parasitize chicken $[29,30]$. There were no chicken farms around the 5 cattle farms where Culicoides were collected in this study. The detection of antigens to AKAV, CHUV, and BEFV in C. arakawae suggests that $C$. arakawae can hold arboviruses antigen although it is not principal vector that transmit 
Table 4. Serum neutralization tests of bovine blood against 5 arboviruses

(A) In data of arboviruses antibody positive based on regions, the AKAV antibody detected in all regions

\begin{tabular}{lccccc}
\hline \multirow{2}{*}{ Region } & \multicolumn{4}{c}{ Arboviruses } \\
\cline { 2 - 5 } & AKAV (\%) & AINOV (\%) & CHUV (\%) & IBAV (\%) & BEFV \\
\hline Wanju & $3.57(1 / 28)$ & 0 & $3.57(1 / 28)$ & 0 & $64.29(18 / 28)$ \\
Gochang & $25.00(10 / 40)$ & 0 & $5.00(2 / 40)$ & 0 & $5.00(2 / 40)$ \\
Gimje & $5.56(1 / 18)$ & 0 & 0 & 0 & $5.56(1 / 18)$ \\
Jinan & $33.33(2 / 6)$ & 0 & 0 & 0 & 0 \\
Namwon & $11.36(5 / 44)$ & 0 & 0 & 0 & 0 \\
\hline
\end{tabular}

(B) Antibody titer which was measured against arboviruses based on regions was considered to be positive if a titer of 4 folds or greater, and BEF showed high titer

\begin{tabular}{|c|c|c|c|c|c|c|}
\hline \multirow{2}{*}{ Region } & \multirow{2}{*}{$\begin{array}{c}\text { Arboviruses positive } \\
\text { number of total } \\
\text { poolings }\end{array}$} & \multicolumn{4}{|c|}{ Arboviruses } & \multirow{2}{*}{$\frac{\left(2^{n}\right)}{B E F V}$} \\
\hline & & AKAV & AINOV & CHUV & IBAV & \\
\hline Wanju & 18 of 28 & $\begin{array}{r}<2 \\
<2 \\
<2 \\
<2 \\
<2 \\
<2 \\
<2 \\
4 \\
<2 \\
2 \\
2 \\
<2 \\
<2 \\
<2 \\
<2 \\
<2 \\
2 \\
2 \\
<2 \\
2 \\
2 \\
2\end{array}$ & $\begin{array}{l}<2 \\
<2 \\
<2 \\
<2 \\
<2 \\
<2 \\
<2 \\
<2 \\
<2 \\
<2 \\
<2 \\
<2 \\
<2 \\
<2 \\
<2 \\
<2 \\
<2 \\
<2 \\
<2 \\
<2\end{array}$ & $\begin{array}{l}<2 \\
<2 \\
<2 \\
<2 \\
<2 \\
<2 \\
<2 \\
<2 \\
<2 \\
<2 \\
<2 \\
<2 \\
<2 \\
<2 \\
<16 \\
16 \\
<2 \\
<2 \\
<2 \\
<2\end{array}$ & $\begin{array}{l}<2 \\
<2 \\
<2 \\
<2 \\
<2 \\
<2 \\
<2 \\
<2 \\
<2 \\
<2 \\
<2 \\
<2 \\
<2 \\
<2 \\
<2 \\
<2 \\
<2 \\
<2 \\
<2 \\
<2\end{array}$ & $\begin{array}{r}32 \\
16 \\
32 \\
16 \\
64 \\
64 \\
64 \\
32 \\
8 \\
64 \\
32 \\
32 \\
128 \\
16 \\
32 \\
64 \\
64 \\
16\end{array}$ \\
\hline Gochang & 12 of 40 & $\begin{array}{l}4 \\
4 \\
4 \\
4 \\
4 \\
4 \\
8 \\
8 \\
2 \\
4 \\
2 \\
4\end{array}$ & $\begin{array}{l}<2 \\
<2 \\
<2 \\
2 \\
2 \\
<2 \\
<2 \\
<2 \\
<2 \\
<2 \\
<2 \\
<2 \\
<2 \\
<2\end{array}$ & $\begin{array}{r}<2 \\
<2 \\
2 \\
<2 \\
<2 \\
<2 \\
<2 \\
4 \\
<2 \\
<2 \\
4 \\
4\end{array}$ & $\begin{array}{l}<2 \\
<2 \\
<2 \\
<2 \\
<2 \\
<2 \\
<2 \\
<2 \\
<2 \\
<2 \\
<2 \\
<2\end{array}$ & $\begin{array}{r}<2 \\
8 \\
2 \\
2 \\
<2 \\
<2 \\
<2 \\
<2 \\
64 \\
<2 \\
<2 \\
<2\end{array}$ \\
\hline Gimje & 2 of 18 & $\begin{array}{r}8 \\
<2\end{array}$ & $\begin{array}{l}<2 \\
<2\end{array}$ & $\begin{array}{l}<2 \\
<2\end{array}$ & $\begin{array}{l}<2 \\
<2\end{array}$ & $\begin{array}{l}<2 \\
16\end{array}$ \\
\hline Jinan & 2 of 6 & $\begin{array}{l}8 \\
8\end{array}$ & $\begin{array}{l}<2 \\
<2\end{array}$ & $\begin{array}{l}<2 \\
<2\end{array}$ & $\begin{array}{l}<2 \\
<2\end{array}$ & $\begin{array}{l}<2 \\
<2\end{array}$ \\
\hline Namwon & 5 of 44 & $\begin{array}{l}4 \\
4 \\
4 \\
4 \\
4\end{array}$ & $\begin{array}{l}<2 \\
<2 \\
<2 \\
<2 \\
<2\end{array}$ & $\begin{array}{l}<2 \\
<2 \\
<2 \\
<2 \\
<2\end{array}$ & $\begin{array}{l}<2 \\
<2 \\
<2 \\
<2 \\
<2\end{array}$ & $\begin{array}{l}<2 \\
<2 \\
<2 \\
<2 \\
<2\end{array}$ \\
\hline
\end{tabular}

arboviruses to ruminants.

When compared with the antigen detection results against arboviruses in Culicoides, the antigen test in the bovine blood did not show any correlation with the type of virus and region. During the study period, there were no reported damages associated with arboviruses, and the appearance and epidemic 
of 5 arboviruses seemed to be rare. On the other hand, antibody test in the bovine serum, antibody to BEFV was detected and the antibody titer was high in one farm (Wanju). As this farm was vaccinated only against $\mathrm{AKAV}$, there is a possibility that the farm might get infected with BEFV. However, there were no virus-related clinical symptoms and the antibody titer can be considered as a maternal antibody. Serological tests using blood were not initially designed and there was a lack of sample number and collection period. In future studies, a large number of blood samples from various regions will be employed to perform the more specific serological examination. In this study, because blood samples were obtained from randomly selected cattle, it was difficult to determine the exact timing of the virus infection. In order to supplement these shortcomings, surveillance study using sentinel cattle that confirmed no-virus infection before investigated year should be conducted.

Previous studies have reported that Culicoides are highly influenced by various environmental factors like temperature, humidity, and wind speed [1,31]. Generally, infections caused by arboviruses and activity rates of Culicoides increase in proportion to rising temperature and are interrupted by wind speed. As a result of our study, we could not confirm the dependent effect of the wind speed. However, the measured values of all the environmental factors had a narrow range and it was difficult to confirm uniformity in results. Therefore, a more frequent sampling will be needed in future studies. Additionally, with respect to the collection of Culicoides from the farm, more Culicoides were collected from outside than inside at low altitude farms $(50 \mathrm{~m})$, while more Culicoides were collected from inside than outside at high altitude farms (300, 500, and $600 \mathrm{~m}$ ). It appeared that Culicoides were attracted by the warmth of the cattle and gathered inside the farm due to lowering of temperatures at higher altitude. However, there was no significant difference in measured temperature inside and outside the farms during the collection period, so the close causal relationship between altitude and mobility of $\mathrm{Cu}$ licoides was not clearly revealed in this study. In South Africa, more Culicoides were collected from old stable than new stable, and more Culicoides were collected from outside than inside the stable [31]. Published study reports about an experiment conducted to compare the sampling rates of females and males Culicoides from inside and outside the farm in Eastern Slovakia [32]. However, there exist not enough studies based on how altitude is related to the abundance of Culicoides. It is not easy to conclude the relationship between the number of collected Culicoides and the environmental factors because altitude alone exactly affects environmental conditions. Therefore, it is necessary to study whether more various conditions affect behavior of Culicoides. Furthermore, through environmental studies on farms that can attract or avoid Culicoides, we may suggest the manuals that farmers can prevent the occurrence of Culicoides related diseases.

\section{ACKNOWLEDGMENT}

This work was supported by the Co-operative Research Program for Agriculture, Science and Technology Development (PJ011978072018) in the Rural Development Administration, Republic of Korea.

\section{CONFLICT OF INTEREST}

The authors declare that there are no conflicts of interest.

\section{REFERENCES}

1. Mellor PS, Boorman J, Baylis M. Culicoides biting midges: their role as arbovirus vectors. Annu Rev Entomol 2000; 45: 307-340.

2. Yanase T, Kato T, Kubo T, Yoshida K, Ohashi S, Yamakawa M, Miura $\mathrm{Y}$, Tsuda T. Isolation of bovine arboviruses from Culicoides biting midges (Diptera: Ceratopogonidae) in southern Japan: 1985-2002. J Med Entomol 2005; 42: 63-67.

3. Patz JA, Frumkin H, Holloway T, Vimont DJ, Haines A. Climate change: challenges and opportunities for global health. JAMA 2014; 312: 1565-1580.

4. Blackwell A, King FC. The vertical distribution of Culicoides impunctatus larvae. Med Vet Entomol 1997; 11: 45-48.

5. Rawlings P. A key, based on wing patterns of biting midges (genus Culicoides Latreille-Diptera: Ceratopogonidae) in the Iberian Peninsula, for use in epidemiological studies. Graellsia 1996; 52: $57-71$.

6. Jennings M, Mellor PS. Culicoides: biological vectors of Akabane virus. Vet Microbiol 1989; 21: 125-131.

7. Parsonson IM, Della-Porta AJ, Snowdon WA. Congenital abnormalities in newborn lambs after infection of pregnant sheep with Akabane virus. Infect Immun 1977; 15: 254-262.

8. Kim YH, Kweon CH, Tark DS, Lim SI, Yang DK, Hyun BH, Song JY, Hur W, Park SC. Development of inactivated trivalent vaccine for the teratogenic Aino, Akabane and Chuzan viruses. Biologicals 2011; 39: 152-157.

9. Oya A, Okuno T, Ogata T, Kobayashi I, Matsuyama T. Akabane, a new arbor virus isolated in Japan. Jpn J Med Sci Biol 1961; 14: 101-108. 
10. Taylor WP, Mellor PS. The distribution of Akabane virus in the Middle East. Epidemiol Infect 1994; 113: 175-185.

11. Bryant JE, Crabtree MB, Nam VS, Yen NT, Duc HM, Miller BR. Isolation of arboviruses from mosquitoes collected in northern Vietnam. Am J Trop Med Hyg 2005; 73: 470-473.

12. Bak UB, Lim CH, Cheong CK, Hwang WS, Cho MR. Outbreaks of Akabane disease of cattle in Korea. Korean J Vet Res 1980; 20: 65-78.

13. Oem JK, Yoon HJ, Kim HR, Roh IS, Lee KH, Lee OS, Bae YC. Genetic and pathogenic characterization of Akabane viruses isolated from cattle with encephalomyelitis in Korea. Vet Microbiol 2012; 158: 259-266.

14. Omori T, Inaba Y, Morimoto T, Tanaka Y, Ishitani R, Kurogi H, Munakata K, Matsuda K, Matumoto M. Ibaraki virus, an agent of epizootic disease of cattle resembling bluetongue. Microbiol Immunol 1969; 13: 139-157.

15. Miura Y, Goto Y, Kubo M, Kono Y. Isolation of Chuzan virus, a new member of the Palyam subgroup of the genus Orbivirus, from cattle and Culicoides oxystoma in Japan. Am J Vet Res 1988; 49: 2022-2025.

16. Mullens BA, Gerry AC, Lysyk TJ, Schmidtmann ET. Environmental effects on vector competence and virogenesis of bluetongue virus in Culicoides: interpreting laboratory data in a field context. Vet Ital 2004; 40: 160-166.

17. Carpenter S, Wilson A, Barber J, Veronesi E, Mellor P, Venter G, Gubbins S. Temperature dependence of the extrinsic incubation period of orbiviruses in Culicoides biting midges. PloS One 2011; 6: e27987.

18. Cho HC, Chong CS. Notes On biting midges of the genus culicoides from South Korea: with special reference to unrecorded species and distribution. Korean J Parasitol 1974; 12: 45-75.

19. Tokunaga M. Notes on biting midges from Japan and Korea (Heleidae or Ceratopogonidae, Diptera). Saikyo Univ Agric 1955; 7: 1-8.

20. Oem JK, Chung JY, Kwon MS, Kim TK, Lee TU, Bae YC. Abundance of biting midge species (Diptera: Ceratopogonidae, Culicoides spp.) on cattle farms in Korea. J Vet Sci 2013; 14: 91-94.

21. Lim SI, Kweon CH, Yang DK, Tark DS, Kweon JH. Apoptosis in Vero cells infected with Akabane, Aino and Chuzan virus. J Vet Sci 2005; 6: 251-254.
22. Conte A, Gilbert M, Goffredo M. Eight years of entomological surveillance in Italy show no evidence of Culicoides imicola geographical range expansion. J Appl Ecol 2009; 46: 1332-1339.

23. Panagiotatos DE. Regional overview of bluetongue viruses, vectors, surveillance and unique features in Eastern Europe between 1998 and 2003. Vet Ital 2004; 40: 61-72.

24. Hope A, Gubbins S, Sanders C, Denison E, Barber J, Stubbins F, Baylis M, Carpenter S. A comparison of commercial light-emitting diode baited suction traps for surveillance of Culicoides in northern Europe. Parasit Vectors 2015; 8: 239.

25. Isberg E, Bray DP, Hillbur Y, Ignell R. Evaluation of host-derived volatiles for trapping Culicoides biting midges (Diptera: Ceratopogonidae). J Chem Ecol 2017; 43: 662-669.

26. Ciliberti P, Meiswinkel R. Culicoides poperinghensis, a new species of biting midge for the Netherlands (Diptera: Ceratopogonidae). Entomolog Ber 2016; 76: 11-14.

27. Thepparat A, Bellis G, Ketavan C, Ruangsittichai J, Sumruayphol S, Apiwathnasorn C. Ten species of Culicoides Latreille (Diptera: Ceratopogonidae) newly recorded from Thailand. Zootaxa 2015; 4033: 48-56.

28. Bellis G, Kim HC, Kim MS, Klein TA, Lee DK, Gopurenko D. Three species of Culicoides Latreille (Diptera: Ceratopogonidae) newly recorded from the Republic of Korea. Zootaxa 2013; 3718: 171-182.

29. Tokunaga M, Takiyama K, Tanaka M, Yoshikawa H. Early Stages and Breeding Place of Culicoides arakawae:(Diptera: Ceratopogonidae). Sci Rep Kyoto Prefect Univ Agric 1961; 13: 53-59.

30. Yu CY, Wang JS, Yeh CC. Culicoides arakawae (Diptera: Ceratopogonidae) population succession in relation to leucocytozoonosis prevalence on a chicken farm in Taiwan. Vet Parasitol 2000; 93: 113-120.

31. Meiswinkel R, Baylis M, Labuschagne K. Stabling and the protection of horses from Culicoides bolitinos (Diptera: Ceratopogonidae), a recently identified vector of African horse sickness. Bull Entomol Res 2000; 90: 509-515.

32. Sarvašová $A$, Kočišová $A$, Liptáková E, Hiavatá $H$, Mathieu B. First insights into indoor and outdoor Culicoides activity related to the risk period for Bluetongue virus transmission in Eastern Slovakia. Acta Parasitol 2016; 61: 743-755. 
Supplementary Table S1. The identity data of BLAST about 5 arboviruses sequence. BLAST results showed that over $92 \%$ identity was observed in 5 arboviruses

\begin{tabular}{|c|c|c|c|}
\hline \multirow{2}{*}{ Virus } & & \multicolumn{2}{|l|}{ BLAST results } \\
\hline & & Detected sequence name & Identity (\%) \\
\hline \multirow{4}{*}{ AKAV } & $\mathrm{F}^{\star}$ & Akabane virus strain 93 FMX S protein mRNA, partial cds & 100 \\
\hline & & Akabane virus isolate 93FMX nucleocapsid protein (N) gene, complete cds & 99 \\
\hline & $\mathrm{R}^{\star}$ & Akabane virus strain 93 FMX S protein mRNA, partial cds & 99 \\
\hline & & Akabane virus isolate 93FMX nucleocapsid protein $(\mathrm{N})$ gene, complete cds & 98 \\
\hline \multirow[t]{2}{*}{ AINOV } & $\mathrm{F}$ & Aino virus $\mathrm{N}$ and NSs genes, segment $\mathrm{S}$, genomic RNA, isolate $38 \mathrm{~K}$ & 99 \\
\hline & $\mathrm{R}$ & Aino virus $\mathrm{N}$ and $\mathrm{NSs}$ genes, segment $\mathrm{S}$, genomic $\mathrm{RNA}$, isolate $38 \mathrm{~K}$ & 99 \\
\hline \multirow[t]{2}{*}{ CHUV } & $\mathrm{F}$ & Chuzan virus genomic RNA for non structural protein NS1, complete cds & 98 \\
\hline & $\mathrm{R}$ & Chuzan virus genomic RNA for non structural protein NS1, complete cds & 95 \\
\hline \multirow[t]{2}{*}{ IBAV } & $\mathrm{F}$ & Epizootic hemorrhagic disease virus (serotype 2 / strain lbaraki) segment 3 & 92 \\
\hline & $\mathrm{R}$ & Epizootic hemorrhagic disease virus (serotype 2 / strain lbaraki) segment 3 & 99 \\
\hline \multirow[t]{2}{*}{ BEFV } & $\mathrm{F}$ & Bovine ephemeral fever virus isolate CS1935 surface glycoprotein (G) gene, partial cds & 99 \\
\hline & $\mathrm{R}$ & Bovine ephemeral fever virus isolate CS1931 surface glycoprotein (G) gene, partial cds & 99 \\
\hline
\end{tabular}

F, Forward; R, Reverse. 


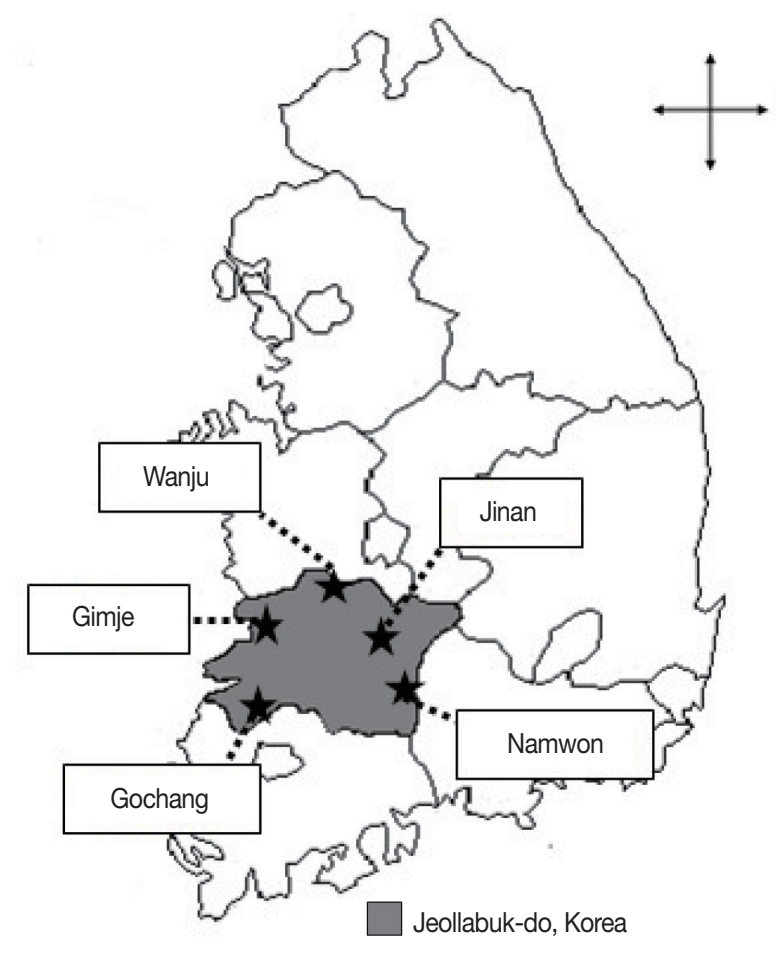

Supplementary Fig S1. Five cattle farms where collected Culicoides biting midges in Jeollabuk-do, Korea. Culicoides biting midges were collected from 5 different cattle farms located in Gimje, Gochang, Wanju, Jinan, and Namwon areas, Jeollabukdo. Two farms (Gimje and Gochang) were located in plain area with low altitude (about $50 \mathrm{~m}$ ), and 3 farms (Wanju, Jinan, and Namwon) were mountainous areas with relatively high altitude (above $300 \mathrm{~m}$ ). 